Sustainable construction and the versatility of the quantity surveying profession in Singapore

\begin{tabular}{|r|l|}
\hline Journal: & Smart and Sustainable Built Environment \\
\hline Manuscript ID & SASBE-07-2021-0125.R2 \\
\hline Manuscript Type: & Original Research Paper \\
\hline Keywords: & $\begin{array}{l}\text { Construction, Cost, Green construction, Singapore, Sustainable } \\
\text { construction, Quantity surveying }\end{array}$ \\
\hline \multicolumn{2}{|l}{} \\
\hline
\end{tabular}




\title{
Sustainable construction and the versatility of the quantity surveying profession in Singapore
}

\begin{abstract}
Purpose- The changing role of quantity surveyors in the new paradigm of sustainable construction requires studies into new competencies and skills for the profession. The impact of sustainable construction on quantity surveying services, engagement and how they manage challenges indicated the success indicators of the quantity surveying profession in meeting the sustainable construction needs.

Design/Methodology/Approach- A five-point Likert scale was developed from the list of quantity surveying firms in Singapore. An $85 \%$ response rate from 60 quantity surveying firms contacted in this study provided 51 responses. Descriptive statistics and factor analysis was employed to evaluate the findings.

Findings- The factor analysis categorised the drivers derived from literature into awareness of sustainable construction, adversarial role on green costing; carbon cost planning; valuing a sustainable property; common knowledge of sustainable construction; and lack of experience in sustainable construction.

Social implications- The research findings supported the idea of increased sustainable construction skills in quantity surveying education, research, and training.

Originality/value- The dearth of quantity surveyors with sustainable construction experience must focus on quantity surveying professional bodies and higher education. The quantity surveying profession needs reskilling in green costing and carbon cost planning to meet the needs of sustainable construction.
\end{abstract}

Author keywords: Construction; Cost; Green construction; Singapore; Sustainable construction; Quantity surveying.

Paper type: Research paper

\section{Background}

Sustainable construction has been touted as a panacea for social, economic, and environmental issues plaguing the construction industry (Yogeshwaran, Perera and Ariyachandra, 2018; Lim, Liu and Oo, 2019; Chamikara, Perera and Rodrigo, 2020; Chandramohan, Perera and Dewagoda, 2020). In attaining sustainable built environment needs, Sodagar and Fieldson (2011), as cited by Bolade-Oladepo et al. (2020), identified the focal areas of sustainable clientship sustainable design; sustainable services design; sustainable cost management; sustainable construction; sustainable operation; and sustainable deconstruction. Based on the aforementioned sustainable built environment aspects, the quantity surveyor's role fits into sustainable construction, cost management, operation, and deconstruction. However, for quantity surveyors to effectively function in these roles, there is a significant need to understand what sustainable construction demands and identify the required skills. The implementation of sustainable construction and their demands differ in various countries. For instance, in Australia, Lim, Liu and Oo, (2019) noted the dearth of sustainable measurement tools, skilled professionals including quantity surveyors in the construction, and ignorance of life cycle costing as some of the limitations quantity surveyors have in regards to sustainable construction. Chamikara, Perera and Rodrigo (2020) discovered that construction technology and environmental services; computer literacy; ethics and professional practice; leadership and management; and measurement and costing are important upskilling areas Sri Lankan quantity surveyors must focus on for effective adoption of sustainable construction. 
In Singapore, Seah (2009) noted that the development of quantity surveyors' skills for sustainable construction has been linked with green costing, carbon footprint, life cycle costing, property performance reporting, green building ratings, and building information modelling (BIM).

The philosophy of sustainability has been cultivated appropriately in Singapore's built environment. Chew (2010) has concurred with implementing sustainable construction in Singapore as this is critically important to a small city-state with scarce natural resources. This is also in line with the statement by Ong (2017) that sustainable urban development is a necessity for small countries, such as Singapore and Hong Kong, to achieve the balance between economic, social and environmental sustainability. The professionals in the industry should take this responsibility very seriously and take steps towards sustainable construction (Bourdeau 1999; Hill and Bowen, 1997; Kibwami and Tutesigensi, 2016). The construction industry has undergone a period of rapid transformation, moving from the traditional design and construction method to new delivery methods suitable for sustainable construction. This indeed provides an opportunity for the quantity surveyors to go beyond their current roles to acclimatise to the new requirements in the industry. Dobson et al. (2013) indicate that sustainable construction requires a broader and long-term view. Recent developments in green buildings have been hindered by the perceived high costs, predominantly from design and construction. These misconceptions can be addressed entirely by introducing green consultants in the market who have adequate expertise concerning sustainable construction. Given the paradigm shift towards sustainability, the current scope of the quantity surveying profession will not be sufficient to stay competitive (Seah, 2009; Yogeshwaran, Perera and Ariyachandra, 2018; Chamikara, Perera and Rodrigo, 2020). Thus, it is necessary for the present quantity surveyors to further enhance their skills and core competencies with a full spectrum for sustainability. This new trend even creates a more significant potential for the quantity surveyors to be equipped with the expertise of providing the latest innovation application, green cost consultancy, cost-effective, sustainable strategies, building material solutions, life cycle cost analysis and property performance assessment. The quantity surveyors, who have sound knowledge of technology and innovation, are critical advisors at all stages of a project lifecycle (Wong 2017; Chamikara, Perera and Rodrigo, 2020; Ahmed et al., 2021). By understanding the building materials and their specifications, the quantity surveyors can perform due diligence, that is, to provide reliable advice on the construction costs and propose a suitable construction method or building materials to attain the desired green building rating. In summary, there is a need to identify the changing roles of quantity surveyors and the opportunities and challenges that surfaced in the light of sustainable construction.

This study aims to examine the impact of sustainable construction on the changing role of Quantity surveyors.

\section{Literature review}

\subsection{Sustainable construction in Singapore}

The notion of sustainable development has been introduced in Singapore since 1992 to agreat extent. The Building and Construction Authority (BCA), an agency under the Ministryof National Development, takes the lead on shaping a safe, high quality, sustainable, and friendly Singapore. The Inter-Ministerial Committee on Sustainable Development (IMCSD) was set up in 2008 to develop a national development strategy towards a sustainable Singapore. To achieve the goal setup by IMCSD, which is to have at least 80 per cent of green buildings by 2030 (BCA 2014; Hwang et al. 2017), the BCA establishes several initiatives in greening the built environment in Singapore. These green initiatives include the introduction of BCA 
Green Mark (a green building rating system adopted in Singapore), the launching of Sustainable Construction Masterplan, amendment of Building Control Act 2008 (Seah 2009) and enhancement of public awareness througheducation. As a result of these initiatives driven diligently by the government, Singapore has been globally recognised as one of the significant countries encouraging the philosophy of sustainability in the built environment through sustainableconstruction practices (Hwang et al., 2017). Langdon and Seah (2012) mention that a new paradigm has emerged across the global construction industry, whereby being environmentally conscious is no longer sufficient. Industry practitioners are required to pay attention to sustainable development. The changing perspective of the construction industry demands the practitioners to react promptly, not to roll with the punches simply, but to manage the changes effectively. The growth of the sustainability market has subsequently created an opportunity to develop sustainability consultancy services from numerous professionals, such as architects, engineers, surveyors, planners, and designers. As stated by Wong (2017), the future technologies in the construction field will be moving towards producing distinctive solutions and flexible components, which attribute to continuous adaptability and cost-

efficiency. Quantity surveyors are well-known as cost specialists in the construction industry, apart from performing the traditional scopes of services. Quantity surveyors need totransform their roles by integrating sustainability principles to remain relevant in the industry.

The concept of sustainable construction has been introduced widely, and hence green buildings are becoming increasingly popular and more evident in the world, especially the United States, Germany, the United Kingdom (Menassa et al. 2012; Rosenow et al. 2013; Hwanget al. 2017) and Singapore (Darko and Chan 2016; Zhao et al. 2016; Hwang et al. 2017). Being a country that has participated in the Paris Climate Change Agreement and been a vocal supporter of environment conservation, Singapore has taken its initiatives towardssustainable development, especially in the built environment (MacKenzie 2017). Singapore has established several longterm goals and plans to achieve its vision of being a clean, green city (Wong 2017). The BCA Green Mark Scheme was introduced in Singapore in January 2005, which has led and served as a benchmark in the tropics and sub-tropics for evaluating environmental sustainability in buildings (Tan, 2015). Various green procurement practices have been successfully promoted across the construction industry under a Sustainable Construction Masterplan. These green procurement practices include adopting environmentally-friendly materials and products in construction projects, recycling and reusi ng construction materials, sustainable design for optimum use of natural materials, amendment of Building Control Act 2008 and accomplishment of Green Mark rating.

As a result of multitudinous efforts put into sustainable development, Singapore's number of green buildings has grown dramatically, from 17 in 2005 to more than 2,100 in 2014 (BCA 2014). The well-known Green Mark award-winning green buildings are Garden by the Bay (Platinum Award 2013), Samwoh Eco-green Building (Platinum Award 2010/2014), Parkroyal on Pickering (Platinum Award 2012) and Resort World Sentosa (Gold Plus Award 2009). Given the myriad benefits of sustainable construction, more developers, designers, consultants, and builders are increasingly focusing on the best practices in environmental design and construction and progressively adopting green building technologies.

\subsection{The changing roles of the quantity surveyor in line with sustainable construction}

The quantity surveying profession has long existed since the $1820 \mathrm{~s}$, which are needed to quantify the building materials and manage cost-related matters in the built environment 
(Mbachu, 2016; Bolade-Oladepo et al., 2020). Thayaparan et al. (2011); Chandramohan, Perera and Dewagoda (2020); Noor, Tobi and Salim (2020); and Yap et al. (2021) reviewed the roles of quantity surveyors over the past centuries and concluded that quantity surveying is a dynamic profession, from its traditional technical roles shift to managerial competencies. Fisher, Coll, Pelly, and Percy (2008) has also reviewed and found out a range of specific sustainability services which the Built Environment Group (consists of Building Control, Building Surveying, Project Management and Quantity Surveying and Construction) can offer to their clients with regards to sustainable development. The $\mathrm{c} \mathrm{e} \mathrm{n} \mathrm{t} \mathrm{r}$ a 1 extents of works of quantity surveying professions under sustainable construction include:

a) Protecting and enhancing the natural environment.

b) Encouraging the sustainable use of resources.

c) Reducing waste generation and responsible disposal of waste.

d) Reducing energy consumption.

e) Promoting community development and social inclusion.

f) Minimising any negative social or environmental impacts ofdevelopment.

g) Promoting sustainable land use and transportation planningand management.

h) Promoting sustainable design, development and constructionpractices, including whole-life costing.

Considering the emerging sustainability market, the quantity surveyors are encouraged to redefine their roles and develop value-added services to accommodate the industry's newly defined demands. This new group of professionals must be transformed from passive individuals to become an influential, central contributor offering various services covering cost advice on sustainable solutions, flexibility in procurement management, risk and value management and exercise of cost engineering (Seah, 2017).

\subsection{Challenges and opportunities for quantity surveyors in sustainable construction}

Going through a period of rapid transformation, the construction industry, including the quantity surveying profession, has experienced changes in sustainable construction. Preece et al. (2011) believe that the phenomenon of sustainable construction is no longer a fad but a full-fledge revolution in the industry. Mbachu (2016) pointed out the opportunities for quantity surveying skill-upgrade for sustainable building, the need for development appraisal, taxation and planning, preliminary cost estimate, and the growing demand for skilled quantity surveyors. Sustainable construction has opened a new insight to the construction community in which the principles of sustainability has been integrated into the design, procurement, and management process of construction projects. Consequently, recent developments in BIM have propounded the application of 4D for schedule management, and 5D BIM for costing, 6D BIM for sustainability and 7D BIM for facilities as some of the cogent requirements for advancing sustainable construction (Shi et al., 2020; Magill et al., 2020). Green costing and carbon cost planning are essential skills quantity surveyors must possess for the effective functioning of the profession in the milieu of sustainable construction (Parker, 2000; Demdoum, Meraghni and Bekkouche, 2021). Hence, advancements in BIM and digitalisation of the construction industry and the urgent need for construction industry 4.0 have placed a requirement for quantity surveyors to further their professional capabilities.

The global sustainability movement poses several challenges across the construction industry, especially in the quantity surveying profession (Bolade-Oladepo et al., 2020; Chamikara, Perera and Rodrigo, 2020). The paradigm shift offers an opportunity for quantity surveyors to go beyond their current roles in cost management. Brümmer (2004) advises the quantity 
surveyors to constantly improve and define the services they could provide, given the changing procurement systems. The transformation of professional practices in the industry is inevitable under the rapid changes, in which Chandramohan, Perera and Dewagoda (2020); Noor, Tobi and Salim (2020); and Harun and Torrance (2006) suggest that the quantity surveyorsshould not be restricted themselves within the boundaries of traditional roles. Quantity surveyors must develop new niches, cultivate new knowledge and explore new skills to enhance competitiveness (Ofori and Toor 2012). As part of the new niches for the quantity surveying profession is green costing. With the advancement of technologies and mechanisms, integrating cost and other relevant data can be done to ensure greater financial transparency on projects.

Ma and Luu (2013) identified the challenges with construction industry professionals in South Australia. The respondents have clarified that the actual demand for quantity surveying services in green projects is not exceptionally high, implying that quantity surveyors have little chance of being involved in green projects. Unlike Building Cost Information Services in the United Kingdom, there is no common database for reference in Singapore's quantity surveying profession, constituting a deficiency in technical competencies. The quantity surveying professions should improve themselves with practical skills and knowledge in sustainable development using research, qualification, attending seminars on sustainable construction and building up cost databases. Furthermore, Wong (2017) has anticipated that the quantity surveying profession will encounter a few challenges in implementing sustainable practices. These include:

a) Less awareness in social responsibility

b) Less awareness in sustainableconstruction

c) The less influential ability that can make current costly sustainable methods more economically viable in the future

d) Additional cost incurred in attending courses or seminars to broaden the quantity surveyors' horizon on sustainable construction technologies, green products or materials, and recycled materials

e) Insufficient cost database on green building services and products

f) Lack of skill and knowledge on Life Cycle Costing and Life CycleAssessment.

The clients are well-informed nowadays and hence more demanding and selective in their requirements on the consultants' professional qualifications to ensure a more efficient

construction value chain (Ofori and Toor, 2012). Under such a critical circumstance, clients today are thus expecting more flexible and broader professional advice holistically on project cost, time, and quality. The pertinent question regarding this investigation is about the nature of sustainable construction skills required for quantity surveyors in Singapore but the influence and relation sustainable construction has on quantity surveyors. The following section consists of a list of hypotheses to address this research question.

\subsection{Research hypotheses}

For an adequate evaluation of the impact of sustainable construction on quantity surveying practice, the following hypotheses were developed to study the engagement, sustainability services, and challenges faced by quantity surveyors in Singapore.

\section{Hypothesis 1}

$\mathrm{H}_{0} 1$ : The development of sustainable construction in Singapore does not significantly affect the engagement of quantity surveyors. 
$\mathrm{H}_{1} 1$ : The development of sustainable construction in Singapore does significantly affect the engagement of quantity surveyors.

\section{Hypothesis 2}

$\mathrm{H}_{0}$ 2: The development of sustainable construction in Singapore does not have a significant effect on new sustainability services offered by quantitysurveyors.

$\mathrm{H}_{1}$ 2: The development of sustainable construction in Singapore significantly affects new sustainability services offered by quantity surveyors.

\section{Hypothesis 3}

$\mathrm{H}_{0} 3$ : There is no significant relationship between the development of sustainable construction in Singapore and challenges in the quantity surveying profession.

$\mathrm{H}_{1} 3$ : There is a significant relationship between the development of sustainable construction in Singapore and challenges in quantity surveying profession.

The following section covers the materials and methods adopted in resolving the research hypotheses.

\section{Materials and methods}

Quantitative research was adopted in this study to achieve the aim of the study, which was to identify the extent of changing roles in the quantity surveying profession with the implementation of sustainable construction practices in Singapore's construction industry. This research was conducted to assess whether Singapore's quantity surveying services have changed under the new wave of sustainable construction development and to study the possible challenges that this profession will encounter. Therefore, a descriptive approach and factor analysis were applied to the research, which aimed to identify the relationship between the variables. A descriptive study must have a clear problem statement, specific hypotheses, and a detailed body of knowledge, which seeks to answer the questions of what, where, who, and when associated with the research problem.

>>Insert Figure $1<<<$

Figure 1 illustrates the quantitative descriptive research design for this research. In quantitative analysis, the data, specifically the numeric data, were gathered using structured research instruments. Furthermore, the research tools such as a questionnaire or computer software were widely applied in the data collection process. The comprehensive analysis of the data collected in this study exploratory factor analysis was used. The exploratory factor analysis is an essential tool for understanding the commonalities and consistencies between variables (Brown and Moore, 2012). Exploratory factor analysis used the Kaiser Meyer Olkin Test and Bartlett's test to assess the reliability of the hypothesis, evaluated the commonalities of each variable and categorised the variables into factors using the scree plot. The categorisation of the variables into factors led to discussions of the factors with relevant literature.

\subsection{Research sampling}

The sample size is a smaller collection of units from a populationselected by the researcher. Choosing the sample size carefully is essential as better sampling gives greater precision to the data (Green and Salkind 2003). A sample population in a research study is the entire group of 
people, events, or things of interest that the researcher wishes to investigate (Mukesh et al., 2013). Regarding the Public Sector Panels of Consultants (PSPC) listing, there were 60 quantity surveying organisations in Singapore - the total number of registered and active quantity surveying firms across Singapore, published by the Building and Construction Authority (BCA) in 2020. Krejcie and Morgan's sample size calculation was based on $\mathrm{p}=0.05$, where the probability of committing type I error was lessthan $5 \%$ or $p<0.05$. The parameter showed that a minimum of 52 quantity surveying firms was deemed appropriate for a population of 60 quantity surveying firms.

$\mathrm{n}=$ $\mathrm{X}^{2} * \mathrm{~N} * \mathrm{P} *(1-\mathrm{P})$

$\left(\mathrm{ME}^{2 *}(\mathrm{~N}-1)\right)+\left(\mathrm{X}^{2} * \mathrm{P} * *(1-\mathrm{P})\right)$

Where:

$\mathrm{N}=$ sample size

$\mathrm{X}^{2}=$ Chi-square for the specified confidence level at 1 degree of freedom

$\mathrm{N}=$ Population size

$\mathrm{P}=$ Population proportion (assumed to be 0.50 to provide themaximum sample size

$\mathrm{ME}=$ Desired Margin of Error (expressed as a proportion).

The sampling method employed in this study was non-probability sampling, which was much easier, faster, and cheaper than probability sampling. Convenience sampling, among the types ofnon-probability sampling, was chosen as the sampling method where the data collection solely relied on the availability and easy access to respondents.

According to Li et al. (2014), it is challenging to determine the exact target population with extensive experience in Singapore's sustainable construction industry and Green Mark certified projects. The sample selection strategy in this study was to identify the quantity surveying firms who have completed Green Mark certified projects based on the information downloaded from the Building and Construction Authority's (BCA) website. The targeted respondents for the survey were the directors, managers, associates, senior executives, and junior executives, who have acquired a range of less than 5 to over 20 years of professional experience in the field of quantity surveying. This range was used because of the total sample size of quantity surveying firms in Singapore.

\subsection{Data collection procedure}

To achieve the aim of this investigation, an online questionnaire survey was administered to the quantity surveyors via Google Forms software. The reason for using a questionnaire survey was that it has the advantage of reaching a representative group of people within a short time frame, providing the means to generate data that can be quantified and analysed, thus allowing the researchers to evaluate different issues by collecting the opinions of people with different backgrounds (Oppenheim 2001; Akadiri 2015). Close-ended questions were selected in the survey to assist the researcher in coding the data without difficulty and restrict the respondents' responses. Thequestionnaire was designed using Google Forms softwarewhich can be easily created to facilitate the data collection process. The questionnaire survey technique was adopted in this study because it was an organised method of collecting data and had been extensively used to collect professional views in sustainable construction research (Hwang et al.2017; Wu and Low, 2012). The main survey questionnaire comprises three sections.

A total of 60 questionnaires were mailed out to participants for completion via their company emails. The respondents were assured of confidentiality and anonymity in their feedback to 
increase the probability of a high response rate (Dobson et al., 2013). Responses were received accordingly, including nine incomplete responses. Afterremoving those, 51 effective responses were received, giving a response rate of $85 \%$. The questionnaire adopted a five-point Likert scale ( 1 = strongly disagree, $2=$ disagree, $3=$ neither, $4=$ agree, $5=$ strongly agree).

\section{Results and analysis}

\subsection{Descriptive statistics of participants' profile}

A frequency analysis was carried out to analyse the demographic background of respondents. The components are gender, age, type of organisation, working experience, position in the organisation, and any previous green projects. The frequency analysis was also used to investigate the respondents' opinions about the quantity surveying profession and sustainable construction growth in terms of anticipated challenges and additional skills required.

A total of 51 responses were collected in this study, and the respondents' demographic background information is presented in Table 1. Among the responses, there were 13 male and 38 female quantity surveyors. The limitations in receiving responses from all 60 quantity surveying firms in Singapore within the cross-sectional time frame of this study were based on the availability of the respondents to respond to the survey. An average of $1.3 \%$ quantity surveyors responded from 40 quantity surveying firms that responded to this survey.

>>Insert Table $1<<<$

Twenty-three respondents $(45.10 \%)$ were below 30 years old, while 18 respondents $(35.30 \%)$ were between 31 and 40 years old. Five respondents $(9.80 \%)$ are between 41 and 50 years old, and another five respondents $(9.80 \%)$ were above 50 years old. $74.51 \%$ of the respondents worked inconsultancy firms, $7.84 \%$ were from contracting companies, developers, and the government sector is $1.96 \%$ each.

Twelve respondents $(23.53 \%)$ worked for less than $\mathrm{five}$ years. Eighteen respondents $(35.29 \%)$ have worked as quantity surveyors for a period of 5 to 10 years. Fourteen respondents $(27.45 \%)$ had a working experience of 10 to 20 years, followed by seven respondents $(13.73 \%)$ with working knowledge of more than 20 years. About half of the respondents, which equates to 24 respondents (47.06\%), were senior executives in their organisation. Besides that, there were 18 junior executives $(35.29 \%)$, two associates $(3.92 \%)$, three managers $(5.88 \%)$, three directors $(5.88 \%)$ and one joint managing partner $(1.96 \%)$ who participated in this questionnaire survey.

Among the respondents, 32 of them $(62.75 \%)$ had been involved in green projects, of which 26 of them $(50.98 \%)$ had taken part in less than ten green projects, 3 of them $(5.88 \%)$ involved in 11 to 20 green projects and another 3 of them (5.88\%) involved in more than 30 green projects. Out of the various types of green projects that the respondents were engaged in, commercial projects had the highest frequency (39.22\%), followed by interior fit-out works (29.41\%),residential projects $(27.45 \%)$, educational projects $(19.61 \%)$, industrial buildings $(13.73 \%)$ and lastly park (3.92\%). Furthermore, $3.92 \%$ of the respondents also participated in other projects $(3.92 \%)$, such as military bases and civil pipelines.

\subsection{Exploratory factor analysis}

The data collected were analysed using the Exploratory Factor Analysis to allow the researchers to explore the underlying theoreticalstructure of data and thus to identify the form of the relationshipbetween the variable and the respondents. The strength of the association was 
determined through the results obtained from the Kaiser Meyer Olkin (KMO) Test for Sampling Adequacy. On the other hand, Bartlett's Test of Sphericity was applied to validate the assumptions made in the research study.

The Kaiser Meyer Olkin test measures sampling adequacy to determine for satisfactory factor analysis to proceed. Bartlett's test is the test for the null hypothesis that the correlation matrix has an identity matrix. The researchers can only reject the null hypothesis when the significant level is below 0.05. Therefore, both the Kaiser Meyer Olkin Test and Bartlett's Test were performed in this study to verify that the components were adequate for subsequent factor analysis. The results were shown in Tables 2, 3 and 4, corresponding to the null hypotheses made in section 2.4 .

\subsubsection{Kaiser Meyer Olkin Test and Bartlett's test for Hypothesis 1}

$\mathrm{H}_{0} 1$ : The development of sustainable construction in Singapore does not significantly affect the engagement of quantity surveyors.

$\mathrm{H}_{1} 1$ : The development of sustainable construction in Singapore does significantly affect the engagement of quantity surveyors.

>>Insert Table $2<<<$

The Kaiser Meyer Olkin Test value was 0.729, which indicated that the sample was adequate and acceptable. From Table 24.14, we can see that Bartlett's Test is significant $(\mathrm{p}<0.001)$. Therefore, the Factor Analysis was valid.

The null hypothesis 1 was rejected as the p-value was lesser than the alpha value, 0.05 . The results suggested that the development of sustainable construction in Singapore does significantly affect the engagement of quantity surveyors.

\subsubsection{Kaiser Meyer Olkin Test and Bartlett's test for Hypothesis 2}

$\mathrm{H}_{0} 2$ : The development of sustainable construction in Singapore does not significantly affect new sustainability services offered by the quantitysurveying profession.

$\mathrm{H}_{1} 2$ : The development of sustainable construction in Singapore significantly affects new sustainability services offered by quantity surveyors.

>> Insert Table $3 \ll<<$

Table 3 shows the test statistics for null hypothesis 2 . The value of the Kaiser Meyer Olkin Test is 0.573 , which is considered barely acceptable. The significance was lower than 0.001 , which was small enough to reject the null hypothesis.

The significant value was lower than the alpha value, 0.05 . Thus we rejected the null hypothesis 2.There was an important relationship between the development of sustainable construction in Singapore and new sustainability services offered by the quantity surveying profession.

\subsubsection{Kaiser Meyer Olkin Test and Bartlett's test for Hypothesis 3}

$\mathrm{H}_{0} 3$ : There is no significant relationship between the development of sustainable construction in Singapore and challenges in the quantity surveying profession.

$\mathrm{H}_{1} 3$ : There is a significant relationship between the development of sustainable construction in Singapore and challenges in quantity surveying. 
A Kaiser Meyer Olkin Test value of 0.666 indicatedthe sample was adequate. The significant valueas shown in Table 4 as less than the alpha value, 0.05 . Therefore, we rejected the null hypothesis $\left(\mathrm{H}_{0} 3\right)$ and accepted the alternate hypothesis $\left(\mathrm{H}_{1} 3\right)$ that there might be a statistically significant relationship between the development of sustainable construction in Singapore and challenges in the quantity surveying profession.

\subsection{Communalities}

Communality is the extent to which a component correlates with other features and is also denoted as $\mathrm{h}^{2}$. Initial communalities indicate the variance in each variable that is accounted for a $\mathrm{n}$ d equal to 1.0 for correlation analyses (IBM Knowledge Center, 2018). Communalities are estimates of the confeach variable accounted for by the components. A higher value of commonalities is better, and a value below 0.30 is considered poor and probably leads to misrepresentation of results. The results are tabulated in Tables 5, 6 and 7 individually.

>> Insert Table $5<<<$

>> Insert Table $6<<<$

>>Insert Table $7<<<$

The communalities of all components in Tables 5, 6, and 7 are above 0.300 and indicate validity and consistency within the variables. The following section presents the eigenvalues and scree plots.

\subsection{Eigenvalues and Scree Plot}

Eigenvalues are defined as the variances of the factors (Bruin, 2011). Eigenvalues and scree tests are statistically used to determine the number of factors retained. As suggested in Kaiser's criterion, the factors above the eigenvalue of 1 are to be included (Yong and Pearce, 2013). The scree test was used in association with the eigenvalues, as shown in Figures 2 to 4.

$>>$ Insert Figure $2<<<$

$>>$ Insert Figure $3<<<$

$>>>$ Insert Figure $4<<<$

In Figure 2, there was a sharp change in the curvature of the scree plot after factor 3. This indicated that after factor 3 , the total variance accounts for smaller and smaller amounts. Figure 3 , the curve started to flatten after factor 3 . In view that the eigenvalues of factors 4 to 7 were less than 1 , therefore only three factors had been retained. There was a sharp change in the curvature of the scree plot after factor 2, as presented in Figure 4. It was shown that factor 3 had an eigenvalue of less than 1 . Thus only two factors had been retained.

\subsection{Rotation}

The interpretability of factors can be improved through rotation by maximising the loading of each variable on one of the extracted factors whilst minimising the loading on all other factors (Field 2005). Varimax was the approach to orthogonal rotation used in this study, and the rotation converged in the $7^{\text {th }}$ iteration.

$>>$ Insert Table $8<<<$

$>>$ Insert Table $9<<<$

>> Insert Table 10<<< 
The rotated matrices in Tables 8, 9 and 10 provided three (3) components in Tables 5 and 6 and 2 in Table 7. The components were used to divide the drivers into the factors, as shown in a combined Table 11. The factors impacting quantity surveyors from hypotheses 1,2 and 3 can be categorised as awareness of sustainable construction; adversarial role on green costing; carbon cost planning; valuing a sustainable property; common knowledge of sustainable construction; and lack of experience in sustainable construction.

>> Insert Table $11<<<$

The contents of Table 11. will be explained in the next section, and the discussion of each factor will be buttressed with the findings from previous studies.

\section{Discussion: Implications of findings}

The implications of Table 11 can be categorised under the broader themes of opportunities and challenges of sustainable construction for the quantity surveying profession. The opportunities are adversarial role on green costing, carbon cost planning, and valuing a sustainable property. The challenges are awareness of sustainable construction, insufficient knowledge of sustainable construction, and lack of experience in sustainable construction. The discussion of the findings has been aligned with the context of the hypotheses, which addressed sustainable construction and engagement of quantity surveyors, new sustainability services offered by quantitysurveyors, and challenges in the quantity surveying profession.

\subsection{Opportunities: Engagement of quantity surveyors in sustainable construction services} 5.1.1 Adversarial role on green costing

In this study, quantity surveyors perceived that insufficient data on green costing could be a significant challenge to engaging in sustainable construction. In general, quantity surveyors are part of the design and cost planning team who engage in the design development of construction projects (Chamikara, Perera and Rodrigo, 2020; Okoye, Odesola and Okolie, 2021). Quantity surveyors' valuable advice on the project cost is exceptionally significant for budgeting and value engineering when necessary (Chamikara, Perera and Rodrigo, 2020). In the case of green construction, Xia et al. (2016) suggested that quantity surveyors require sustainability literacy. Sustainability education is central to fostering knowledge of green construction.

Ma and Luu (2013) agreedthat quantity surveyors with adequate green costing knowledge would have a more competitive advantage in providing clients with detailed and accurate cost advice. Notwithstanding the Green Mark rating system that was launched in Singapore in 2005. In this investigation, quantity surveyors presumed that the lack of understanding of the Green Mark system would probably turn this profession away from providing sustainability services. This may subsequently affectthe appointment of quantity surveyors in future green projects. The quantity surveyors conjectured that the bad experience in green projectswas the main challenge to stay relevant in the new development.

Consequently, early engagement of quantity surveyors in green projects is beneficial in establishing sustainability education and experience. As part of the project team, the quantity surveyors must participate in developing and integrating sustainability strategy at the initial stage. Ma and Lu (2013) and Bolade-Oladepo et al. (2020) mentioned that clients count on quantity surveyors, owing to their thorough understanding of green products and materials. Quantity surveyors are the critical advisors at all stages of the project life cycle, and they must have excellent knowledge of the use of sustainable construction materials, technologies and 
designs. The adversarial role of quantity surveyors in the construction industry can be enhanced for sustainable construction through organisational developmental policies.

\subsubsection{Carbon cost planning and accounting}

The most common sustainability service delivered by quantity surveying organisations in Singapore is cost estimate and cost planning. Quantity surveying organisations involved in sustainable construction conducted feasibility studies for green projects. The quantity surveyors were appointed to perform their due diligence to assess the practicality of proposed green developments. There was a wide range of green projects involving the respondents, such as residential, commercial, interior fitting out and infrastructures. Feasibility studies in sustainable construction are of utmost importance before the commencement of a project because it provides an understanding of the project's scope, schedule, and cost (Russell et al., 2012). The findings of this study revealed that quantity surveying organisations prepared the bill of quantities and tender documents for green projects. Wong (2017) highlighted the traditional roles of quantity surveyors in the building delivery process applicable to every project as being pre-and post-contract cost planning and control. The pre-contract process generally included cost planning and estimating, procurement strategising, preparation of tender documents and tender evaluation. Through life cycle costing (LCC) analysis, quantity surveyors can differentiate between the recurring and non-recurring costs of a building, examine the up-front development and capital costs in addition to the operation and maintenance expenditures. Under a constrained budget, LCC analysis can facilitate a better capital allocation for operations, maintenance, and other future costs. LCC analysis had been applied to green projects for a holistic assessment. Therefore, there is a need for the inclusion of LCC intertwined with carbon cost planning and accounting to be relevant further and higher education curriculum, not only in Singapore but around the world. The inclusion of carbon cost planning in the quantity surveying practice is an opportunity to engage future and existing quantity surveyors in sustainable construction.

\subsubsection{Valuing sustainable property}

Property Performance Reporting (PPR) was embedded as a new service within quantity surveying organisations in Singapore. PWC (2014) stated that buildings with poor sustainability performance led to a shorter operational life. Given the building lifespan and cyclical movements on the market, property performance will need to be measured and evaluated against the variousperformance indicators to retain the properties' value and lengthen their lifespan. Nevertheless, quantity surveying organisations carry out the Carbon Footprint Assessment (CFA) for their clients to value sustainable property. Areas with low energy can be identified through CFA. Seah (2009) discusses that the existing performance measurement tools can be improved towards a balanced strategy, focusing on energy efficiency. The quantity surveyors are to execute a PPR system to provide independent risk assessments that evaluate and benchmark property performance against contemporary standards and propose practicable measures against international and industry standards, government reporting targets, property measurement norms, and rating tools. Hence, existing quantity surveyors in Singapore and globally must up-skill their PPR and CFA knowledge through continuing professional development (CPD) events organised by the RICS and local quantity surveying regulatory bodies. 


\subsection{Challenges: The quantity surveyor's readiness for sustainable construction services and engagement}

\subsubsection{Awareness of sustainable construction}

Inadequate awareness of sustainable construction is a significant challenge facing the quantity surveying profession (Lim, Liu and Oo, 2019; Bolade-Oladepo et al., 2020). The question of what sustainable construction entails for quantity surveying practice is still evolving. As educational and organisational institutions are trying to enhance their curriculum and professional competency, emerging concepts from sustainable construction keep changing professional requirements. Construction industry 4.0 and digitalisation is making the quantity surveying profession more dynamic and versatile. Therefore, the pressure for more awareness of sustainable construction needs in pedagogy and client's requirement has become a challenge. The attentiveness of the quantity surveyors to their changing roles in sustainable construction is not favourable. Thus, most of the respondents in this study perceived their roles as unnecessary as the architects and engineers in promoting sustainable construction. The respondents also noted that the additional cost incurred for attending courses and seminars was regarded as a minor issue in implementing sustainability services.

Given that a new market of sustainability services has been created in the construction industry, the implementation of sustainable construction has presented new challenges and unique opportunities to the quantity surveying profession. The sustainability movement has a significant impact on the quantity surveyors. Jan (2015) opined that the rising demand has led to new and unprecedented roles for quantity surveyors to support the growth of the sustainability market. Given the changinglandscape in the construction industry, Ofori and Toor (2012) urged that the construction community should not simply cope with developments in sustainability but be proactive in driving the need for change. Moreover, Wong (2017) has also suggested that the roles of quantity surveyors should be developed continuously to stay relevant and sophisticated in the industry. Ma and Luu (2013) have raised their concerns on the transformation of the role of professionals, in particular the quantity surveyors, "Are there any changes to the traditional functions of Quantity Surveyor, under the new wave of theGreen Building Development?" The current quantity surveyors must embrace the rapid changes and raising demands about sustainable constructionoprovide superior and more comprehensive services to the market.

\subsubsection{Low knowledge of sustainable construction}

Then another challenge experienced by quantity surveyors in Singapore was inadequate understanding of green products and materials, corresponding to Wong's findings in 2017. Unlike the architects and engineers who have an extraordinary knowledge of the building materials and design, the quantity surveyors were less exposed to much information on sustainable products andmaterials. The quantity surveyors may have lesser knowledge of the specifications of green materials, alternative materials, and recycled materials. Besides, Wong (2017) has carried out a case study in Singapore to investigate the expanded roles executed by quantity surveyors in a BCA Green Mark Platinum building project, known as Khoo Teck Puat Hospital (KTPH). The responsibilities of quantity surveyors with green design expertise have been identified as follows:

a) Allocate sufficient budget with the cost information available in the local context, bearing in mind current market conditions

b) Provide cost advice during the design development stage and ensure the costs are under control 
c) Execute life cycle cost analysis and ensure that both costs and credits for green features are accounted for

d) Update cost estimate as and when required.

e) Value engineering on green materials to be used for theproject.

f) Maintain a database of green building products from variousspecialists and suppliers

g) Review final biddocuments.

The BCA Green Mark Platinum building project has exposed the knowledge level of quantity surveyors in Singapore as being inadequate. In this regard, the challenge of meeting the required skills itemised in a) to g) above is predicated on educational and organisational willingness to drive sustainable construction knowledge as a culture of advancing the course of the quantity surveying profession.

\subsubsection{Lack of experience in sustainable construction}

Inadequate green expertise and information was the most critical issue raised by quantity surveying respondents in this study. The dearth of appropriate green expertise can lead to poor performance in providing a comprehensive sustainability service. Ma and Luu (2013) further explained that the quantity surveying profession had less involvement in green projects due to low market demand. Research conducted by Ma and Luu (2013) in South Australia has enforced the statement that the roles of quantity surveyors have been evolving under the implementation of sustainable construction. Ma and Luu (2013) identified and confirmed that the quantity surveying firms in South Australia had offered new and relevant services to the market with the growing demand for green buildings. However, based on their findings, only $45 \%$ of respondents agreed that quantity surveyors play an essential role in promoting green building development. Nonetheless, it is concluded that the quantity surveyors must acquire additional skills and knowledge to remain relevant in the green development era. The quantity surveying profession can enhance its versatility by engaging in green construction projects from a broader perspective.

\subsection{Implication for academic practice}

The quantity surveying profession has been described as dynamic and versatile in responding to changes (Yogeshwaran, Perera and Ariyachandra, 2018; Chamikara, Perera and Rodrigo, 2020; Noor, Tobi and Salim, 2020). However, there is a challenge of updating further and higher education curriculum, continuing professional development, and upskilling experienced quantity surveyors to meet the requirement of sustainable construction. The outcomes of previous studies conducted by Ma \& Luu (2013); Yogeshwaran, Perera and Ariyachandra, (2018); Chamikara, Perera and Rodrigo, (2020); Noor, Tobi and Salim (2020); Seah (2009); Mbach, (2016); and Bolade-Oladepo et al. (2020) confirm the need for the quantity surveying education sector to adopt new concepts such as sustainable cost management in addition to the traditional roles of the quantity surveyor. Similarly, the lack of awareness of sustainable construction in the quantity surveying profession can be addressed through specialist seminars, conferences and workshops.

\section{Conclusion and limitations of the study}

This study focused on the relationship between the development of sustainable construction in Singapore and the expanded roles of quantity surveyors. The outcome of the study explicated that thedevelopment of sustainable construction in Singapore had asignificant effect on the engagement of quantity surveyors and the sustainability services offered by quantity surveyors. The roles of quantity surveyors are expanding to accommodate new market demands, which result in a wide-ranging sustainability service. The most common services offered were 
sustainable cost estimating and carbon cost planning, feasibility studies, and bill of quantities for green projects. Redefining the roles and value-added services is essential for the quantity surveying professions to align with the new industry of intense competition, client-centricity and technology advancements.

Various services were provided, such as cost estimate and planning for green projects, feasibility studies of green projects, Life Cycle Cots analysis, Carbon Footprint Assessment, Green Mark scheme advisory, and Property Performance Reporting. The involvement of quantity surveyors in green projects is paramount towards building a sustainable nation in Singapore. Nevertheless, the construction professions have experienced emerging challenges and unknowns in implementing sustainable development goals. Most of the professions are suffering from a lack of appropriate green expertise, information and understanding. Hence, there is a need for quantity surveyors to acquire the newest skills and knowledge for better performance and enhancement of their competencies to remain relevant in theindustry. The necessary measures include but are not limited to attending courses, seminars, training, and workshops on sustainable construction. This study was solely carried out in Singapore. It is recommended that the study be conducted in other countries to improve the current review on the roles of quantity surveyors. The research is limited to identifying the changing roles of quantity surveyors under sustainable construction in Singapore. Further studies utilising qualitative and quantitative methods should be conducted to identify the emerging sustainable construction roles of quantity surveyors in the built environment.

Data Availability Statement: All of the data, models, or code that support the findings of this study are available from the corresponding author upon reasonable request.

Conflict of Interest: Authors declare no conflict of interest in this study

\section{References}

Ahmed, A. M. et al. (2021) 'Identifying barriers to the implementation and development of sustainable construction, International Journal of Construction Management. Taylor \& Francis, Vol. 1, pp. 1-12. Doi: 10.1080/15623599.2021.1967577.

Akadiri, P.O. (2015). "Understanding barriers affecting the selection of sustainable materials in building projects". Journal of Building Engineering,Vol. 4, pp. 86 - 93. https://doi.org/10.1016/j.egypro.2017.03.743

Ali, Z. and Bhaskar, S.B. (2016). Basic statistical tools in research anddata analysis. Indian Journal of Anaesthesia, Vol. 60 No.9, pp. 662 - 669. Doi: 10.4103/0019$\underline{5049.190623}$

Bamgbade, J.A., Kamaruddeen, A.M. and Nawi, M.N.M. (2017). Malaysian construction firms" social sustainability via organisational innovativenessand government support: The mediating role of market culture. Journal of Cleaner Production, Vol.154, pp. 114 - 124. https://doi.org/10.1016/j.jclepro.2017.03.187

Bolade-Oladepo, Funmilola, A., Oladipo, Francis, O. and Fasuyi, O.A. (2020) 'Sustainable built environment: the role of quantity surveyors', IOSR Journal of Engineering (IOSRJEN) www.iosrjen.org ISSN, Vol. 10 No. 1, pp. 2278-8719. http://iosrjen.org/Papers/vol10_issue1/Series-1/A1001010106.pdf 
Bruin, J., (2011). Factor Analysis SPSS Annotated Output. [online] Available from: https://stats.idre.ucla.edu/spss/output/factor-analysis/ [Accessed 26 May 2018].

Building and construction authority (BCA) (2014). $3^{\text {rd }}$ Green Building Masterplan. Available from https://www.nccs.gov.sg/docs/default-source/newsdocuments/3rd_green_building_masterplan.pdf [Accessed 25 May 2018]

Chamikara, P. B. S., Perera, B. A. S. and Rodrigo, M. N. N. (2020) 'Competencies of the quantity surveyor in performing for sustainable construction', International Journal of Construction Management. Taylor \& Francis, Vol. 20 No.3, pp. 237-251. Doi: 10.1080/15623599.2018.1484848.

Chandramohan, A., Perera, B. A. K. S. and Dewagoda, K. G. (2020) 'Diversification of professional quantity surveyors' roles in the construction industry: the skills and competencies required', International Journal of Construction Management. Taylor \& Francis, Vol. 2, pp. 1-8. Doi: 10.1080/15623599.2020.1720058.

Chetty, P. and Datt, S. (2015). Interpretation offactor analysis using SPSS. [online] Available from:https://www.projectguru.in/publications/interpretation-of-factor-analysisusing-spss/ [Accessed 22 May 2021].

Chew, KC (2010). Singapore's strategies towards sustainable construction. The IES Journal Part A: Civil \& Structural Engineering, Vol. 3 No. 3, pp.196 - 202. https://doi.org/10.1080/19373260.2010.491641

Darko, A. and Chan, A.P.C. (2016). Critical analysis of green building research trend in construction journals. Habitat International, Vol. 57, pp. 53 - 63. https://doi.org/10.1016/j.habitatint.2016.07.001

Davis Langdon (2007). The cost and benefit of achieving greenbuildings. Australia: Davis Langdon. Santa Monica, CA: Davis Langdon. Retrieved from Davis_Langdon_Info_Data_Cost_and_benefit.pdf [Accessed 25 May 2018]

Davis Langdon (Australia) (2009). The Blue Book: Accessible Knowledgefor the Property $\&$ Construction Industry, $11^{\text {th }}$ Ed. Australia: Davis Langdon. Santa Monica, CA: Davis Langdon. Retrieved from https://www.yumpu.com/en/document/read/3969441/the-blue-book-davis-langdon [Accessed on 25 May 2018]

Demdoum, Z., Meraghni, O. and Bekkouche, L. (2021) 'The Application of Green Accounting According to Activity-Based Costing for an Orientation Towards a Green Economy: Field Study', International Journal of Digital Strategy, Governance, and Business Transformation (IJDSGBT). IGI Global, 11(1), pp. 1-15.

Dobson, D.W., Sourani, A., Sertyesilisik, B. and Tunstall, A. (2013). Sustainable Construction: Analysis of Its Costs and Benefits. AmericanJournal of Civil Engineering and Architecture, Vol. 1 No. 2, pp. 32 38. http://dx.doi.org/10.12691/ajcea-1-2-2 
Feldstein, B. (2016). Principal Component Analysis Vs Exploratory FactorAnalysis. [online] Available from:

http://activisiongamescience.github.io/2016/02/09/Principal-Component- Analysisvs-Exploratory-Factor-Analysis/ [Accessed 22 May 2018].

Fisher, R., Coll, L., P, L. and Percy, J. (2008). Surveying sustainability: a short guide for the property professional. The Appraisal Journal. Vol. 76, No. 1, pp. 15-22.

Harun, H. and Torrance, J.A. (2006). Drivers of change: new challenges for the quantity surveyors, in International Conference on ConstructionIndustry 2006: Toward Innovative Approach in Construction and Property Development, Kuala Lumpur, Malaysia. https://doi.org/10.18576/asuj/040105

Heffner, C.L. (2014). Chapter 7.3 Test Validity and Reliability. [online] Available from: https://sixsigmastudyguide.com/non-parametric/ [Accessed3 May 2018].

Hill, RC and Bowen, P.A. (1997). Sustainable construction: Principles and a framework forattainment. Construction Management and Economics, Vol. 15 No.3, pp. 223 - 239. https://doi.org/10.1080/014461997372971

Hwang, B.G., Shan, M. and Supa'at, N.N. (2017). Green commercialbuilding projects in Singapore: Critical risk factors and mitigation measures. Sustainable Cities and Society, Vol. 30, pp. 237 - 247. https://doi.org/10.1016/j.scs.2017.01.020

Hwang, B.G., Zhu, L., Wang, Y. and Cheong, X. (2017). Green Building Construction Projects in Singapore. Project Management Journal, Vol. 48 No. 4, pp. 67 - 79. https://doi.org/10.1177/875697281704800406

IBM knowledge center (2018). Communalities. [online] Available from: https://www.ibm.com/support/knowledgecenter/SSLVMB_23.0.0/spss/tu tori als/fac_cars_communalities_01.html [Accessed 23 May 2018].

Jan, D.B (2015). Sustainable Building New Challenge for QuantitySurveyors. [online] Available from:http://www.engineeringnews.co.za/article/sustainable-building-newchallenge-for-quantity-surveyors-2015-08-26/rep_id:4136 [Accessed 18January 2021].

Kibwami, N. and Tutesigensi, A. (2016). Enhancing sustainable construction in the building sector in Uganda. Habitat International, Vol. 57, pp. $64-73$. https://doi.org/10.1016/j.habitatint.2016.06.011

Li, Y.Y., Chen, P-H., Chew, ASD and Teo, C.C. (2014). Exploration of critical resources and capabilities of design firms for delivering green building projects: Empirical studies in Singapore. Habitat International, Vol. 41, pp. $229-235$. https://doi.org/10.1016/j.habitatint.2013.08.008

Lim, B. T. H., Liu, A. Z. J. and Oo, B. L. (2019) 'Awareness and practices of sustainable construction in Australia: Consultant quantity surveyors' perception', AIP Conference Proceedings, 2124(July). DOI: 10.1063/1.5117120. 
Ma, T. and Luu, H.T. (2013). The Changing Role of Quantity Surveyors in theGreen Building Development in South Australia, in 38th AUBEA Conference, University of Auckland. Retrieved from https://ap01a.alma.exlibrisgroup.com/view/delivery/61USOUTHAUS_INST/12143309220001831 [ Accessed 25 May 2018]

Mackenzie, D. (2017). Commentary: Green buildings, Singapore "s natural ally for a greener future. [online] Singapore: Channel NewsAsia. Available from: https://www.channelnewsasia.com/news/singapore/commentary-green-buildingsSingapore-s-natural-ally-for-a-9183380 [Accessed 3 February 2018].

Magill, L. J. et al. (2020) '4D BIM integrated construction supply chain logistics to optimise on-site production', International Journal of Construction Management. Taylor \& Francis, 0(0), pp. 1-10. DOI: 10.1080/15623599.2020.1786623.

Mbachu, J. (2016) 'Quantity surveyor's role in the delivery of construction projects : A review Quantity surveyor 's role in the delivery of construction projects : A review', (September 2015). available from:

www.researchgate.net/profile/Jasper_Mbachu/publication/306235887_Quantity_survey or\%27s_role_in_the_delivery_of_construction_projects_A_review/links/57b410fb08ae ac3177851812/ Quantity-surveyors-role-in-the-delivery-of-construction-projects-Areview.pdf [Accessed May 28, 2018].

Menassa, C., Mangasarian, S., EL Asmar, M. and Kirar, C. (2012). Energy consumption evaluation of US Navy LEED-certified buildings. Journalof Performance of Constructed Facilities, Vol. 26 No. 1, pp. $46-53$. https://doi.org/10.1061/(ASCE)CF.1943-5509.0000218

Moore, M. T. and Brown, T. A. (2012) 'Hoyle CFA Chapter - Final Running head: Confirmatory Factor Analysis Timothy A . Brown and Michael T . Moore Correspondence concerning this chapter should be addressed to Timothy A . Brown, Center for Anxiety \& Related Disor', (July 2012).

Mukesh, K., Salim, A.T. and Ramayah, T. (2013). Business ResearchMethods. Shah Alam: Oxford. ISBN: 97898347074779834707479

Noor, S. N. M., Tobi, S. U. M. and Salim, K. R. (2020) 'Competencies of Quantity Surveyors in Construction Industry: Document Reviews from Different Quantity Surveyor Professional Bodies', in IOP Conference Series: Materials Science and Engineering. IOP Publishing, p. 12098. Doi: 10.1088/1757-899X/864/1/012098

Ofori, G. and Toor, S.R (2012). Role of Leadership in Transforming the Profession of Quantity Surveyor. The Australasian Journal of Construction Economics and Building, Vol. 9 No. 1, pp. 37 - 44. https://doi.org/10.5130/AJCEB.v9i1.3013

Okoye, P. U., Odesola, I. A. and Okolie, K. C. (2021) 'Barriers to Sustainable Construction Practices (Case Study: The Role of National Culture)', International Journal of Architecture and Urban Development, 11(2), pp. 5-20. 
Oppenheim, A.N. (2001). Questionnaire Design, Interviewing and Attitude Measurement, New Edition. New York: Continuum. ISBN: 1855670437

Parker, L. D. (2000) 'Green strategy costing: Early days', Australian Accounting Review. Wiley Online Library, 10(20), pp. 46-55. DOI: 10.1111/j.1835-2561.2000.tb00054.x

Preece, C., Low, S.P., Padfield, R. and Papargyropoulou, E., (2011). Developing and marketing sustainable construction services. Management and Innovation for a Sustainable Built Environment. 20 - 23 June 2011, Amsterdam, The Netherlands ISBN: 9789052693958.

PWC (2014). Real Estate 2020: Building the future. [online] Available from: https://www.pwc.com/sg/en/real-estate/assets/pwc-real-estate-2020-building-thefuture.pdf [Accessed 27 May 2018].

Rosenow, J., Eyre, N., Bürger, V. and Rohde, C. (2013). Overcoming the upfront investment barrier - Comparing the German $\mathrm{CO} 2$ building rehabilitation programme and the British green deal. Energy and Environment, Vol. 24 No. 1-2, pp. 83 - 103. https://doi.org/10.1260/0958-305X.24.1-2.83

Russell, D.A., Ivano, D.F. and Daniele, D.F. ( 2012). The Six-Phase Comprehensive Project Life Cycle Model Including the Project Incubation/Feasibility Phase and the Post-Project Evaluation Phase. PM World, Vol. 1 No. 5, pp 1 - 40. Retrieved from: https://pmworldlibrary.net/wp-content/uploads/2013/01/PMWJ5-Dec2012ARCHIBALD-DI-FILIPPO-Featured-Paper1.pdf [Accessed 28 May 2018]

Seah, E. (2009). Sustainable construction and the impact on the quantity surveyor', in Bowers, D. et al. (eds) 13th Pacific Association of Quantity Surveyors Congress (PAQS 2009).

Shi, A. et al. (2020) '5D BIM Applications in Quantity Surveying: Dynamo and 3D Printing Technologies', Smart Cities and Construction Technologies. BoD-Books on Demand, p. 139. DOI: 10.5772/intechopen.91221

Tan, T.C. (2015). Singapore's $3^{\text {rd }}$ Green Building Master Plan: Moving Forward with Green. Retrieved from: https://www.nparks.gov.sg//media/cuge/ebook/citygreen/cg10/cg10_sg_3rd_green_building_master_plan.pdf?la= en\&hash=47C2A885074480BF9BB185C5C5FCD126D80722C9 [Accessed 17 June 2018].

Thayaparan, M., Siriwardena, M.L., Amaratunga, R.D.G., Malalgoda, C.I. and Keraminiyage, K.P. (2011). Lifelong learning and the changing roleof the quantity surveying profession, in 15th Pacific Association of Quantity Surveyors Congress (PAQS 2011). Retrieved from: https://core.ac.uk/download/pdf/1665771.pdf [Accessed 17 May 2018].

Udeaja, C., Ekundayo, D., Zhou, L., Pearson, J. and Perera, S. (2015). Mapping Sustainability in the Quantity Surveying Curriculum: Educating Tomorrow's Design 
Economists. In: Robinson, H., Symonds, B., Gilbertson,B. and Ilozor B, $1^{\text {st }}$ ed. Design Economics for the Built Environment: Impact of Sustainability on Project Evaluation. John Wiley \& Sons Ltd, pp. 372 - 386. Doi: $\underline{10.1002 / 9781118944790}$

Wao, JO (2015). Predicting the future of quantity surveying Profession in the construction industry. Journal of ConstructionProject Management and Innovation, Vol. 5 No. 2, pp. 1211 - 1223. https://hdl.handle.net/10520/EJC183324

Weemss, (2016). Sustainable Development and the 3 Pillars Of Sustainability. [online]

Available from:https://weemss.com/blog/sustainable-development-3-pillarssustainability/ [Accessed 8 February 2021].

Wong, Y. M., ( 2017). The expanded role of quantity surveyors ingreen buildings. Available at:www.nziqs.co.nz/Portals/9/PAQS/Abstracts/260\%20\%20y\%20wong.pdf [accessed January 19, 2021].

Xia, B. et al. (2016). 'Improving sustainability literacy of future quantity surveyors', Smart and Sustainable Built Environment. Vol. 5 No. 4, pp. 325-339 https://doi.org/10.1108/SASBE-07-2016-0015

Yap, J. B. H. et al. (2021). 'Assessing the expected current and future competencies of quantity surveyors in the Malaysian built environment', Engineering, Construction and Architectural Management. Vol. ahead-of-print No. ahead-of-print. doi: 10.1108/ECAM-01-2021-0091.

Yogeshwaran, G., Perera, B. A. S. and Ariyachandra, M. R. F. (2018) 'Competencies expected of graduate quantity surveyors working in developing countries, Journal of Financial Management of Property and Construction. Emerald Publishing Limited, Vol. 23 No.2, pp. 202-220. DOI: 10.1108/JFMPC-06-2017-0019.

Yong, A.G. and Pearce, S. (2013). A Beginner's Guide to Factor Analysis: Focusing on Exploratory Factor Analysis. Tutorials in Quantitative Methods for Psychology, Vol. 9 No. 2, pp. 79 - 94. Retrieved from: https://www.tqmp.org/RegularArticles/vol092/p079/ [Accessed on 12 March 2018]

Zhao, X., Hwang, B.G. and Gao, Y. (2016). A fuzzy synthetic evaluation approach for risk assessment: A case of Singapore's green projects. Journalof Cleaner Production, Vol. 115, pp. 203 - 213. https://doi.org/10.1016/j.jclepro.2015.11.042 
List of Figures

\begin{tabular}{|c|c|}
\hline & Descriptive Research \\
\hline Objective & $\begin{array}{l}\text { To evaluate the changing roles of quantity surveying } \\
\text { professions in sustainable construction in Singapore. }\end{array}$ \\
\hline $\begin{array}{l}\text { Problem } \\
\text { Statement }\end{array}$ & $\begin{array}{l}\text { How do the quantity surveyor professions evolve in } \\
\text { dealing with the changing demands under the } \\
\text { implementation of sustainable construction? }\end{array}$ \\
\hline Process & $\begin{array}{l}\text { 1. Administer online questionnaire survey } \\
\text { 2. Document responses } \\
\therefore \text { Analyse data } \\
\text { +. Describe outcomes }\end{array}$ \\
\hline Outcomes & $\begin{array}{l}\text { - Quantitative data } \\
\text { - } 1 \text { ndings can be presented in frequencies, } \\
\text { / } r \text { :entages and mean scores. }\end{array}$ \\
\hline
\end{tabular}

Figure 1. The quantitative descriptive research design used in the study.

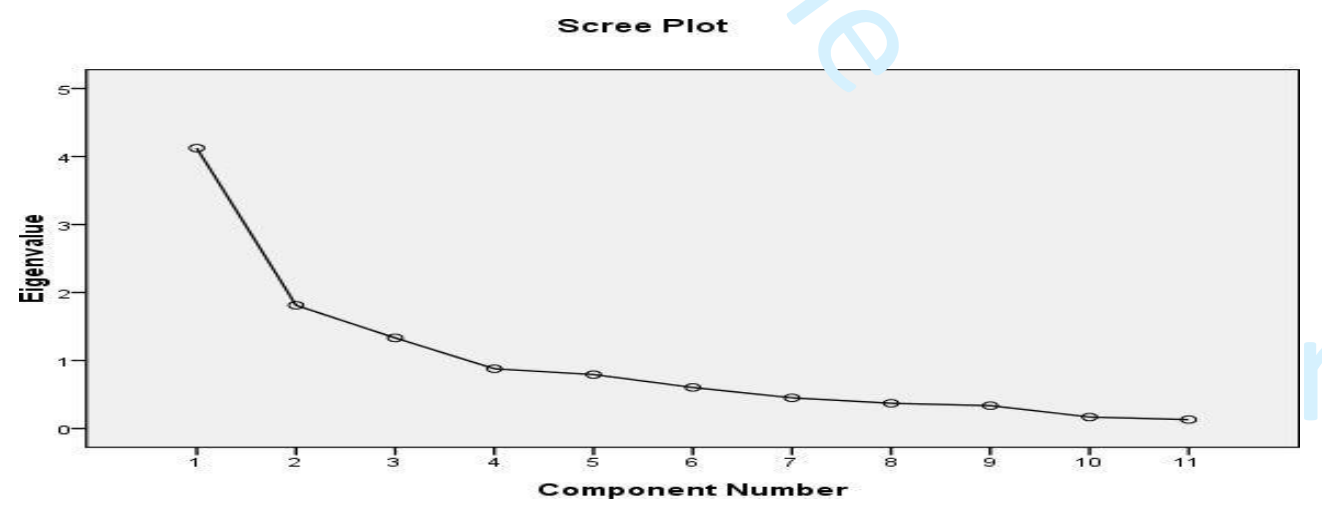

Figure 2. Scree Plot for hypothesis 1.

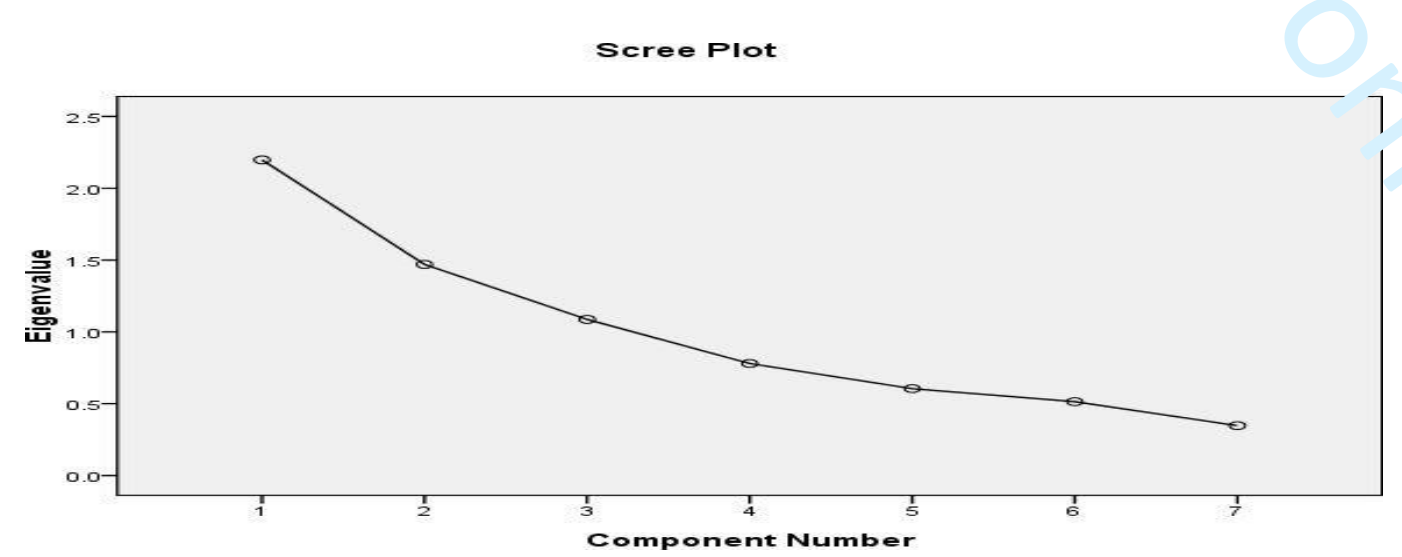


Figure 3. Scree Plot for hypothesis 2

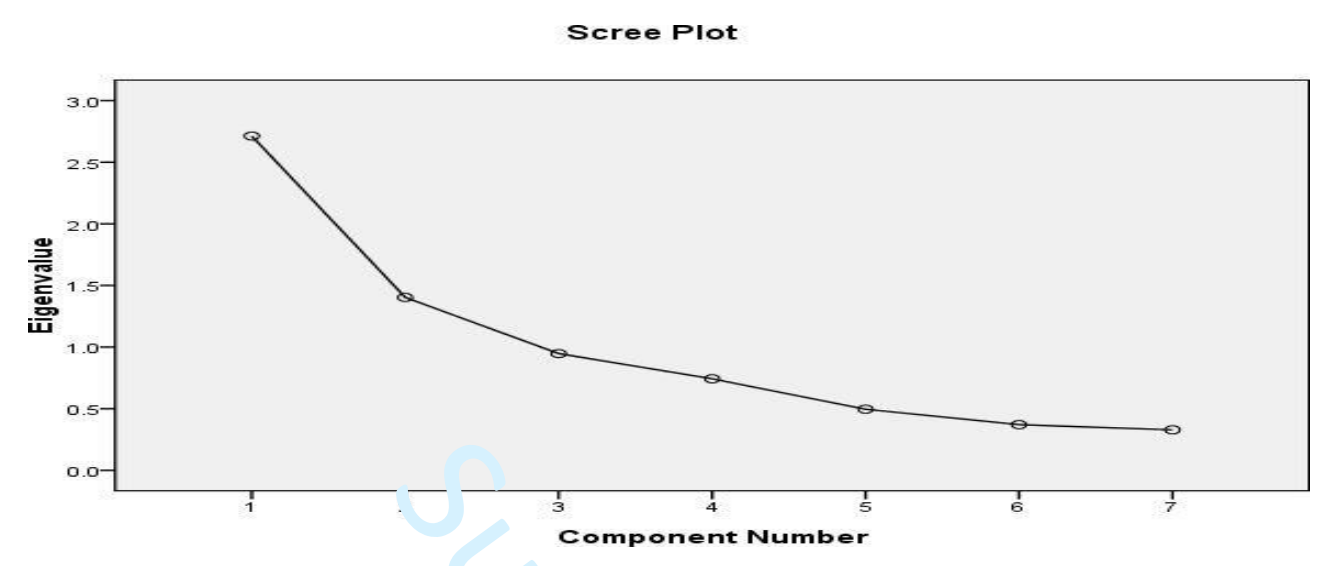

Figure 4. Scree Plot for hypothesis 3 
List of Tables

Table 1. The demographic background of samples.

\begin{tabular}{|c|c|c|}
\hline Construct and Dimensions & Frequency & $\begin{array}{c}\text { Percentage } \\
(\%)\end{array}$ \\
\hline \multicolumn{3}{|l|}{ Gender } \\
\hline Male & 13 & 25.49 \\
\hline Female & 38 & 74.51 \\
\hline \multicolumn{3}{|l|}{ Age } \\
\hline Below 30 years old & 23 & 45.10 \\
\hline $31-40$ years old & 18 & 35.30 \\
\hline $41-50$ years old & 5 & 9.80 \\
\hline Above 50 years old & 5 & 9.80 \\
\hline \multicolumn{3}{|l|}{ Quantity Surveying Organisation } \\
\hline Consultancy & 38 & 74.51 \\
\hline Contracting & 4 & 7.84 \\
\hline Contractor & 7 & 13.73 \\
\hline Developer & 1 & 1.96 \\
\hline Government Sector & 1 & 1.96 \\
\hline \multicolumn{3}{|l|}{ Years of Working Experience } \\
\hline Less than 5 years & 12 & 23.53 \\
\hline $5-10$ years & 18 & 35.29 \\
\hline $10-20$ years & 14 & 27.45 \\
\hline More than 20 years & 7 & 13.73 \\
\hline \multicolumn{3}{|l|}{ Position in Organisation } \\
\hline Junior Executive & 18 & 35.29 \\
\hline Senior Executive & 24 & 47.06 \\
\hline Associate & 2 & 3.92 \\
\hline Manager & 3 & 5.88 \\
\hline Director & 3 & 5.88 \\
\hline Joint Managing Partner & 1 & 1.96 \\
\hline \multicolumn{3}{|l|}{ Involvement in Green Projects } \\
\hline Yes & 32 & 62.75 \\
\hline No & 19 & 37.25 \\
\hline \multicolumn{3}{|l|}{$\begin{array}{l}\text { Ivumber or Greenrrojects } \\
\text { Involved }\end{array}$} \\
\hline No & 19 & 37.25 \\
\hline Less than 10 projects & 26 & 50.98 \\
\hline $11-20$ projects & 3 & 5.88 \\
\hline $21-30$ projects & 0 & 0.00 \\
\hline More than 30 projects & 3 & 5.88 \\
\hline \multicolumn{2}{|l|}{ Types of Green Project } & \\
\hline $\begin{array}{l}\text { Residential } \\
\text { Yes }\end{array}$ & 14 & 27.45 \\
\hline No & 37 & 72.55 \\
\hline \multicolumn{3}{|l|}{ Commercial } \\
\hline Yes & 20 & 39.22 \\
\hline No & 31 & 60.78 \\
\hline \multicolumn{3}{|l|}{ Educational } \\
\hline Yes & 10 & 19.61 \\
\hline No & 41 & 80.39 \\
\hline \multicolumn{3}{|l|}{ Industrial } \\
\hline Yes & 7 & 13.73 \\
\hline No & 44 & 86.27 \\
\hline \multicolumn{3}{|l|}{ Interior Fit-Out } \\
\hline Yes & 15 & 29.41 \\
\hline
\end{tabular}


NO

Parks

Yes 2

No

Others

Yes

No

Table 2. Kaiser Meyer Olkin Test and Bartlett's Test Results for Hypothesis 1.

\begin{tabular}{|c|c|c|}
\hline & rest & Value \\
\hline \multicolumn{2}{|c|}{ Kaiser-Meyer-Olkin Measure of Sampling Adequacy. } & 0.729 \\
\hline \multirow[t]{3}{*}{ Bartlett's Test of Sphericity } & Approx. Chi-Square & 239.606 \\
\hline & df & 55 \\
\hline & Sig. & 0.000 \\
\hline
\end{tabular}

Table 3. Kaiser Meyer Olkin Test and Bartlett's Test Results for Null Hypothesis 2.

\begin{tabular}{|c|c|}
\hline Test & Value \\
\hline Kaiser-Meyer-Olkin Measure of Sampling Adequacy. & 0.573 \\
\hline \multirow[t]{3}{*}{ Bartlett's Test of Sphericity } & 57.095 \\
\hline & 21 \\
\hline & 0.000 \\
\hline
\end{tabular}

Table 4. Kaiser Meyer Olkin Test and Bartlett's Test Results for Null Hypothesis 3

\begin{tabular}{|c|c|c|}
\hline & Test & Value \\
\hline \multicolumn{2}{|c|}{ Kaiser-Meyer-Olkin Measure of Sampling Adequacy. } & 0.666 \\
\hline \multirow[t]{3}{*}{ Bartlett's Test of Sphericity } & Approx. Chi-Square & 85.425 \\
\hline & $d f$ & 21 \\
\hline & Sig. & 0.000 \\
\hline
\end{tabular}

Table 5. Communalities of components for hypothesis 1

\begin{tabular}{lll}
\hline $\mathbf{N r}$ & \multicolumn{1}{c}{ Driver } & Extraction \\
\hline 1 & $\begin{array}{l}\text { QS plays an important role in promoting sustainable construction. } \\
\text { Early engagement of QS in green projects helps establish sustainability } \\
\text { targets }\end{array}$ & 0.661 \\
3 & $\begin{array}{l}\text { QS can advise on the use of sustainable construction materials, technologies } \\
\text { and designs. }\end{array}$ & 0.859 \\
\hline
\end{tabular}


Table 6. Communalities of components for hypothesis 2

\begin{tabular}{llr}
\hline $\mathbf{N r}$ & \multicolumn{1}{c}{ Driver } & Extraction \\
\hline 1 & Feasibility studies for Green Projects & 0.622 \\
2 & Cost Estimate and Cost Plan for Green Projects & 0.791 \\
3 & Preparing Bill of Quantities for Green Projects & 0.533 \\
4 & Life Cycle Cost Analysis & 0.923 \\
5 & Carbon Footprint Assessment & 0.604 \\
6 & Advice on Green Mark Scheme & 0.588 \\
7 & Property Performance Reporting & 0.694
\end{tabular}

Table 7. Communalities of components for hypothesis 3

\begin{tabular}{|c|c|c|}
\hline $\mathbf{N r}$ & Drivers & Extraction \\
\hline 1 & $\begin{array}{l}\text { Inadequate understanding of green products and } \\
\text { materials }\end{array}$ & 0.561 \\
\hline 2 & Inadequate green expertise and information & 0.798 \\
\hline 3 & $\begin{array}{l}\text { Insufficient cost data on green designs, products, and } \\
\text { materials }\end{array}$ & 0.424 \\
\hline 4 & Inadequate experiences in green projects & 0.668 \\
\hline 5 & Inadequate understanding of Green Mark System & 0.362 \\
\hline 6 & Inadequate awareness on sustainable construction & 0.629 \\
\hline 7 & $\begin{array}{l}\text { Additional costs incurred for attending courses and } \\
\text { seminars }\end{array}$ & 0.674 \\
\hline
\end{tabular}

5 Carbon Footprint Assessment plays an important role in achieving the energy cost-effectiveness of a building.

8 Cost-Benefit Analysis plays an important role in evaluating sustainable solutions for green developments

$\begin{array}{lll}9 & \text { The cost model is important in achieving the preferred Green Mark rating. } & 0.490 \\ 10 & \text { QS plays an important role in the application of BIM. } & 0.484\end{array}$

0.789 seminars

Table 8. Rotated Component Matrix for hypothesis 1

\begin{tabular}{|c|c|c|c|c|}
\hline \multirow{2}{*}{ CODE } & \multirow{2}{*}{ Drivers } & \multicolumn{2}{|c|}{ Component } & \\
\hline & & 1 & 2 & 3 \\
\hline $\mathrm{A} 1$ & $\begin{array}{l}\text { QS plays an important role in promoting } \\
\text { sustainable construction. }\end{array}$ & 0.763 & & \\
\hline $\mathrm{A} 2$ & $\begin{array}{l}\text { Early engagement of QS in green projects } \\
\text { helps establish sustainability targets }\end{array}$ & 0.896 & & \\
\hline
\end{tabular}




\begin{tabular}{|c|c|c|c|c|}
\hline A3 & $\begin{array}{l}\text { QS can advise on the use of sustainable } \\
\text { construction } \\
\text { materials, technologies, and designs. }\end{array}$ & 0.502 & 0.371 & \\
\hline A4 & QS can advise on green costing appropriately. & 0.345 & 0.765 & \\
\hline A5 & $\begin{array}{l}\text { Carbon Footprint Assessment plays an } \\
\text { important role in achieving the energy } \\
\text { efficiency of a building. }\end{array}$ & & & 0.783 \\
\hline A6 & $\begin{array}{l}\text { QS can perform as a cost and carbon } \\
\text { management consultant. }\end{array}$ & 0.414 & & 0.613 \\
\hline A7 & $\begin{array}{l}\text { The Life Cycle Costing technique plays an } \\
\text { important role in achieving the cost- } \\
\text { effectiveness of a building. }\end{array}$ & & 0.862 & \\
\hline A8 & $\begin{array}{l}\text { Cost-Benefit Analysis plays an important role } \\
\text { in evaluating } \\
\text { sustainable solutions for green developments. }\end{array}$ & & 0.853 & 0.321 \\
\hline A9 & $\begin{array}{l}\text { The cost model is important in achieving the } \\
\text { preferred Green Mark } \\
\text { rating. }\end{array}$ & 0.436 & 0.532 & \\
\hline A10 & $\begin{array}{l}\text { QS plays an important role in the application of } \\
\text { BIM. }\end{array}$ & & & 0.620 \\
\hline A11 & QS can perform Property Performance Report. & 0.784 & & 0.316 \\
\hline
\end{tabular}

Table 9. Rotated Component Matrix for hypothesis 2

\begin{tabular}{|l|l|l|l|l|}
\hline \multirow{2}{*}{ CODE } & \multicolumn{1}{|c|}{ Drivers } & \multicolumn{2}{c|}{ Component } \\
\cline { 5 - 5 } & & \multicolumn{1}{c|}{1} & \multicolumn{1}{c|}{3} \\
\hline B1 & Feasibility studies for Green Projects & 0.730 & & \\
\hline B2 & Cost Estimate and Cost Plan for Green Projects & 0.798 & & 0.387 \\
\hline B3 & Preparing Bill of Quantities for Green Projects & 0.718 & & \\
\hline B4 & Life Cycle Cost Analysis & & & 0.960 \\
\hline B5 & Carbon Footprint Assessment & & 0.751 & \\
\hline B6 & Advice on Green Mark Scheme & 0.315 & 0.689 & \\
\hline B7 & Property Performance Reporting & & 0.801 & \\
\hline
\end{tabular}

Table 10. Rotated Component Matrix for hypothesis 3

\begin{tabular}{|l|l|c|c|}
\hline \multirow{2}{*}{ CODE } & \multicolumn{1}{|c|}{ Driver } & \multicolumn{2}{c|}{ Component } \\
\cline { 3 - 4 } & & 1 & 2 \\
\hline C1 & Inadequate understanding of green products and materials & 0.733 \\
\hline C2 & Inadequate green expertise and information & & 0.893 \\
\hline
\end{tabular}




\begin{tabular}{|l|l|c|c|}
\hline C3 & $\begin{array}{l}\text { Insufficient cost data on green designs, products, and } \\
\text { materials }\end{array}$ & 0.650 & \\
\hline C4 & Inadequate experiences in green projects & 0.649 & 0.498 \\
\hline C5 & Inadequate understanding of Green Mark System & 0.536 & \\
\hline C6 & Inadequate awareness on sustainable construction & 0.658 & 0.442 \\
\hline C7 & Additional costs incurred for attending courses and seminars & 0.773 & \\
\hline
\end{tabular}

Table 11. Sustainable construction factors affecting quantity surveyors

\begin{tabular}{|c|c|c|c|c|}
\hline $\mathbf{N r}$ & Factors & $\begin{array}{l}\text { Hypothesis } \\
1\end{array}$ & $\begin{array}{l}\text { Hypothesis } \\
2\end{array}$ & $\begin{array}{l}\text { Hypothesis } \\
3\end{array}$ \\
\hline 1 & $\begin{array}{l}\text { Awareness of sustainable } \\
\text { construction }\end{array}$ & $\begin{array}{ll}A 1 ; & A 2 ; A 3 ; \\
A 4 ; & A 6 ; \\
\text { A11. }\end{array}$ & & \\
\hline 2 & $\begin{array}{l}\text { Adversarial role on green } \\
\text { costing }\end{array}$ & A7; A8; A9; & $\mathrm{B} 1 ; \mathrm{B} 2 ; \mathrm{B} 3$ & \\
\hline 3 & Carbon cost planning & $A 5 ; A 10$ & B4 & \\
\hline 4 & $\begin{array}{l}\text { Valuing sustainable } \\
\text { property }\end{array}$ & & B5; B6; B7 & \\
\hline 5 & $\begin{array}{l}\text { Low knowledge of } \\
\text { sustainable constructi }\end{array}$ & & & $\mathrm{C} 1 ; \mathrm{C} 2$; \\
\hline 6 & $\begin{array}{l}\text { Lack of experience in } \\
\text { sustainable construction }\end{array}$ & & & $\begin{array}{l}\text { C3; C4; C5; } \\
\text { C6; C7 }\end{array}$ \\
\hline
\end{tabular}

